\title{
The Transition from Sex to Gender in English Prisons: Human Rights and Queer Theory
}

\author{
Michael Biggs*
}

(16 May 2020)

The very subject of women is no longer understood in stable or abiding terms.

—Judith Butler (1989, p. 1)

Her penis was erect and sticking out of the top of her trousers.

-Charlotte Dangerfield prosecuting Karen White (Evans, McCann, and Rudgard 2018)

Should a rapist - more precisely, a person who has used his penis to rape a woman - be placed in a women's prison if he claims to be a woman? ${ }^{1}$ This question came to prominence in Britain during the contest for leadership of the Labour Party. All three final candidates expressed their conviction that anyone who declares themselves to be a woman must be treated as a woman in every respect. One of the candidates, Lisa Nandy, explicitly stated that rapists could be incarcerated with women (Fisher and Karim 2020). She was responding to a question posed by Julia Long, a radical feminist who campaigns for female-only spaces. Long used the example of Christopher Worton, convicted of multiple rapes starting when the female victim was aged 13, and who subsequently took the name Zoe Lynes (Dresch 2019). This individual case opens up a far broader policy question: should our institutions erase biological sex, as observed, and replace it by gender identity, as declared? Western countries have transitioned at least some way from sex to gender in the last decade, as transgender activists have won influence within government and within organizations like universities and corporations. The success of activists is intriguing because they represent a tiny minority and so lack electoral weight or purchasing power. Moreover, their claims are opposed by a majority of the public. Only $12 \%$ of British adults believe that a male who identifies as a woman yet retains his penis and testicles should be imprisoned in a women's prison (Populus 2018). Surely the proportion would be considerably less if that male had committed sexual offences against women. Yet an English judge ruled in 2009 that a rapist should be placed in the women's estate, and prison regulations were changed in 2011 and again in 2016 to facilitate such transfers.

Prisons are a critical domain for the contest between sex and gender. Traditionally, prisons have been separated by sex. There is a massive disparity between the two prison populations. In England and Wales, there are 21 male prisoners for every female (Ministry of

\footnotetext{
* Department of Sociology, University of Oxford. Mathis Ebbinghaus and Susan Matthews provided useful comments. My interest in this topic was sparked by Gallus Mag's writing about Synthia China Blast.

${ }^{1}$ Under English law, rape is a crime committed only by males: it now requires penetration by a penis (Sexual Offences Act 2003), and previously was defined as perpetrated by a 'man' (Sexual Offences Act 1956).
} 
Justice 2020a). A far higher proportion of prisoners in the men's estate are convicted of sex offenses: $19 \%$ compared to $4 \%$. Put another way, $98.5 \%$ of sexual offenders in prison are male. Conversely, there is evidence that women in prison are more vulnerable to sexual predation. About $36 \%$ of women recall being sexually abused as children, compared to $6 \%$ of male prisoners (Williams, Papadopoulou, and Booth 2012). Transferring males to women's prisons therefore has real implications for female inmates. By contrast, transferring females to men's prisons is less significant because transgender female prisoners are few in number, they rarely wish to transfer, and they pose less of a threat. ${ }^{2}$

This paper analyses the gradual erasure of sex in the prison system in England and Wales. It traces the succession of criteria for allocating males to women's prisons: first genital surgery, then legal sex, and finally gender identity. These changes can be explained by two distinct forces. The most important initially was the expansion of human rights in the spheres of imprisonment and healthcare, largely through judicial decisions. These interacted to produce unintended outcomes. Prisoners won the right to health care equal to that provided outside prison; transsexual patients won the right to genital surgery. Put together, these cases established a right for prisoners to obtain genital surgery, which in turn enabled them to move to the women's estate. When clinicians decreed that the prerequisite for genital surgeryliving as a woman - could be met only in a women's prison, then it naturally followed that male prisoners desiring genital surgery had to be transferred before surgery. This landmark legal ruling put the first rapist into a women's prison in 2009. In response, the prison service introduced the criterion of legal sex, which an individual could now change due to the Gender Recognition Act of 2004.

The Act manifested the second important causal force, which I will call queer theorythough applied postmodernism or intersectional feminism would do as well. Judith Butler is the pivotal theorist, even though the term just postdated her classic work. 'To expose the foundational categories of sex, gender, and desire as effects of a specific formation of power' is the preliminary task for queer theory (Butler 1990, p. ix). This ultimate goal is to 'disrupt the categories of the body, sex, gender, and sexuality and occasion their subversive resignification and proliferation beyond the binary frame' (p. x). Queer theory has the character of self-fulfilling prophecy (Biggs 2009): insisting that sex is not a stable foundation while destabilizing it in order to make the theory come true. This paradoxical blend of positive and normative is similar to neoclassical economics, which theorizes how the markets work while exhorting its champions to eliminate market 'imperfections' which impede the theory's operation (MacKenzie 2006). The power of economic theories to shape our world is obvious. Queer theory, I argue, also has constitutive power. What began as esoteric academic doctrine soon evolved to inspire activists and shape campaigns. It influenced the formulation of the Gender Recognition Act, the first law in the world to allow someone to change legal sex without undergoing any physical change (Whittle and Turner 2007). Queer theory motivated activists who in 2015 launched a social media campaign to transfer a violent male to the women's estate. This successful campaign was followed by two suicides in prison, which were given prominence in the mainstream media. These events persuaded the government to revise prison regulations, advised by Gendered Intelligence - an organization founded upon queer theory. The regulations of 2016 established gender identity as the criterion by which males would be allowed to enter women's prisons, albeit hedged with

\footnotetext{
${ }^{2}$ To illustrate the last point, 17 transgender males have committed murder or attempted murder in England and Wales since 2010, compared to 1 transgender female (Trans Crime 2019).

${ }^{3}$ The term initially denoted theorizing about gay and lesbian sexuality (de Lauretis 1991), but soon accrued the broader meaning used here (Jagose 1997).
} 
some qualification. These regulations allowed about two dozen males in to the women's estate. Predictably, one sexually assaulted female inmates. The paper ends with this case, which illuminates the consequences of putting queer theory into practice.

This paper focuses narrowly on the incarceration of males in women's prisons. ${ }^{4}$ It excludes important topics pertaining to the treatment of transgender prisoners in the men's estate: segregation, as for example in a hospital wing or Vulnerable Prisoner Unit; restrictions on clothing and the provision of feminine accoutrements like wigs and cosmetics; and the availability of cross-sex hormones. The paper concentrates on the forces promoting the transition from sex to gender, and so does not consider the countermobilization by dissident feminists which became significant from 2017 onwards. Geographically the paper is restricted to the prison system of England and Wales. Scotland has followed a similar trajectory (Murray and Blackburn 2019), and the same policy shift has occurred throughout the Englishspeaking world, from New Zealand to the United States.

Terminology is inevitably controversial with this subject. I use the terms transsexual or transgender as appropriate for the era under discussion. Circumlocutions such as 'a preoperative, pre-hormone therapy, male-to-female transgender prisoner' (Law Society of Ireland 2019) will be eschewed in favour of simple adjectives like male. The use of pronouns to affirm gender identity rather than denote biological sex reflects - and arguably enablesthe policy shifts analysed here. Because the application of female pronouns to males erodes our ability to recognize differences in the propensity to violence and sexual predation, especially when dealing with men convicted of crimes against the person, I will not adhere to this convention. Instead, transsexual and transgender people are referred to by name. For males who declared a feminine identity only after incarceration, I provide the name under which they were convicted as well as their subsequent feminine name.

\section{Genital surgery}

By the 1980s, males who had undergone genital surgery before conviction could be placed in women's prisons. Gloria Greaves was sentenced in 1983 to eighteen months for living off immoral earnings and was imprisoned in HMP Holloway, a women's prison, even though only a man could commit that crime (Daily Mail 1982). From the 1980s to 2009, the prison service followed a clear rule: only transsexuals who had genital surgery could be placed in a prison for the opposite sex. The nature of this surgery was not specified, and so it is not clear whether orchidectomy-removing the testicles - would suffice, or whether vaginoplastyinverting the penis to create an artificial vagina - was also required. (There is no record of any transman being incarcerated in a men's prison in this period. In the early 2010s, the first transman was moved after having a phalloplasty - grafting an artificial penis.) As the Director General of the Prison Service stated to Parliament, 'the principal criteria is the most obvious physical characteristics of the person concerned and their ability to integrate with other inmates. A male-to-female transsexual who has undergone surgery and hormone treatment would therefore be more appropriately allocated to a female establishment' (House of Commons, 18 May 1994, 460W).

The Director General's statement reveals the emergence of political advocacy for transsexual prisoners. The parliamentary question was asked by Alex Carlile, a Liberal Democrat. He was a staunch ally of Press for Change, which had been founded in 1992 to campaign for transsexual rights. Labour Member of Parliament Lynne Jones wanted to 'house pre-operative transsexuals in the gaols of their new gender if they have had two or more years of hormone therapy' (House of Commons Debates, 22 May 1995, 496W). This suggestion

\footnotetext{
${ }^{4}$ Also excluded is sentencing: there are cases where a court withholds a custodial sentence to avoid incarcerating a transgender criminal in a men's prison (Swerling 2020).
} 
was more radical than the guidelines for transsexual prisoners endorsed by Press for Change and written by Kate More. A leading figure in the Gender and Sexuality Alliance, More was an enthusiast for queer theory, editing a newsletter called Radical Deviance and interviewing Judith Butler (More and Butler 1999). Yet More proposed only that prisoners who identified themselves as transsexual should be kept in a hospital unit, and after clinical diagnosis should be moved to a specialist unit which 'could be attached to a women's prison' (More 1996). Possibly these demands were moderated because the Home Secretary, Michael Howard, was known for his harsh stance on law and order. ${ }^{5}$

When Labour took power in 1997, Press for Change could hope to influence government policy. The Home Office commissioned research on prisons from Stephen Whittle, the leading activist in Press for Change and a Lecturer in Law at Manchester Metropolitan University (Whittle 2002, p. 217). Whittle eventually recommended that all prisoners 'posttransition but prior to completion of all desired surgical procedures' must be 'housed in facility of appropriate gender role' (2002, p. 235). But this was not taken up by the government. The Interdepartmental Working Group on Transsexual People (2000, p. 14) recognized 'problems in placing a [pre-operative] male-to-female transsexual person in a female establishment, where she may not be accepted by other prisoners, many of whom may have suffered violent or sexual abuse from men'. This statement, incidentally, is unusual for recognizing the vulnerability of incarcerated women, though it is framed in terms of their acceptance of the transsexual.

The provision covering transsexuals who already had genital surgery applied to a tiny number of people. Only one other besides Greaves is listed in Emerton's (2018) comprehensive account: Stephanie Booth, sentenced in 1989 to twelve weeks for a video licensing offence (Meierhans 2015). Existing prisoners were not eligible for genital surgery. By the late 1990s, at least one male was pursuing legal action on this point. John Pilley had been sentenced (in 1981) to life for kidnapping a woman at knifepoint. In prison he took the name Jane Anne and was prescribed cross-sex hormones. Pilley then argued that it was unfair for the service to deny genital surgery - which naturally would enable transfer to a women's prison (Burrell 1999). Pilley prevailed in 1999, after a legal decision in another domain. Three patients launched a judicial review against their NHS health authority for refusing to fund genital surgery. They won the case in the High Court in 1998 (Regina $v$ North West Lancashire Health Authority). The prison service was already committed to providing healthcare equivalent to that provided by the NHS, and therefore it could no longer refuse to provide genital surgery (Goodchild 2000). Pilley underwent an orchidectomy and was eventually transferred to a women's prison, HMP Holloway. (It is not clear whether Pilley also had a vaginoplasty.) Carlile declared this to be an 'important step towards giving transsexuals proper civil liberties' (Burrell 1999). There was no concern for the women who would now be incarcerated with a male who had committed serious violence against a woman. Curiously, some years later Pilley renounced his feminine identity and so required further genital surgery in order to return to a men's prison (Ford 2006).

The 1999 decision, paradoxically, enabled only the most violent and predatory males to transfer to women's prisons. For the NHS Gender Identity Clinic to approve genital surgery, the patient on cross-sex hormones would have to 'live and work in their female role for two years'. As Russell Reid, the clinic's consultant psychiatrist pointed out, 'this is very difficult,

\footnotetext{
${ }^{5}$ According to Playdon (2004, p. 148), More's guidelines became the basis of a draft 'Prison Service Guidelines on the Care, Management and Treatment of Prisoners with Gender Dysphoria' (1999). In response to my request, 'a thorough search has been carried out across a number of departments within the MoJ, including library services, archives, and all relevant policy units', but no such document was located (Ministry of Justice 2020b).
} 
though not impossible for them to fulfil' (Burrell 1999). In practice, therefore, surgery was available only to prisoners serving lengthy sentences. An example was Douglas Wakefield, sentenced to life (in 1974) for beating and stabbing his uncle to death. In prison he strangled and beat to death another inmate, and attempted to kill a warden. To experience life as a woman, Wakefield took the name Tai, decorated his cell with lace curtains and flowers, and wore earrings. Genital surgery subsequently enabled Wakefield to relocate to a women's prison, HMP New Hall (Francis 2013).

\section{Legal sex}

Press for Change's crowning success was the Gender Recognition Act of 2004, which enabled anyone to apply to be recognized legally as the opposite sex. Incarceration was not specifically mentioned in the bill. In parliament, however, Labour Minister David Lammy stated that prisoners 'can apply and ... will be subject to prison arrangements for their new acquired gender' (Parliamentary Debates, 23 February 2004, c52). In fact, prison placement was still determined by genitalia. By 2006, at least twelve prisoners had undergone genital surgery (Williams 2006). Press for Change argued that male prisoners who obtained a gender recognition certificate should be transferred to a women's prison, but their argument had no discernible effect on policy (Whittle, Turner, and Al-Alami 2007).

The change in policy came about, as in 1999, as the unintended consequences of a decision taken outside the prison system. Mark Jones had been imprisoned (in 2001) for strangling his boyfriend, supposedly after a dispute about Jones' intention to become transsexual. Jones concealed the body so it decomposed, which hindered prosecution; he could only be convicted of manslaughter. A few days after release from prison, while staying in a women's bail hostel, Jones attempted to rape a woman who worked in a shop selling transvestite clothing. (It was attempted rape only because Jones failed to maintain an erection.) For this crime Jones, now using the name Karen, was sentenced to life imprisonment. In prison Jones was given cross-sex hormones and laser hair removal, and obtained a certificate under the Gender Recognition Act. The problem was that the NHS Gender Identity Clinic now decided that living as a woman was impossible in a men's prison, even though that had been possible for Pilley and at least eleven others. And the Clinic would soon approve a female prisoner's phalloplasty even while the prisoner remained in a women's prison (Emerton 2018, pp. 297-8). Whatever the reason behind the change in policy, it placed the prison system in a double bind, as Jones observed: 'They will not consider me as a female until I have my penis removed ... Yet they resist moving me to the female estate which would enable the surgery to be arranged' (AB 2009, para 8).

Jones brought a judicial review in 2009. The decisive factor for the judge, David Elvin QC, was Article 8 of the European Convention of Human Rights which guarantees respect for private and family life. The landmark 2002 decision by the European Court of Human Rights - which precipitated the Gender Recognition Act-had interpreted this article as creating a right to change legal sex. Because the prison system did not provide sufficient justification to keep Jones in a men's prison, Elvin ordered Jones to be transferred to a women's prison. The argument that Jones would be hard to manage in a women's prison was dismissed on the grounds that Jones would pose still greater difficulties if thwarted, due to what the consultant forensic psychologist described as 'narcissistic, compulsive, aggressive, violent and sadistic elements' in his personality (para 63).

The rights of the women who would have to share facilities with such a person were ignored. Indeed, James Barrett from the Gender Identity Clinic was concerned only for the welfare of Jones: 'there will probably always be a small number of prisoners who will choose to make an issue of the matter because they are the sort of women who enjoy conflict. If this patient is able to cope with protracted close proximity [with] women of that sort I would 
judge her able to cope with the less prolonged, more avoidable, travails of the civilian world' (AB 2009, para 70). One might think that a attempting to rape a woman would count as evidence against the claim to be 'a woman trapped inside a man's body', but Jones' legal team had appealed against his second sentence by using gender dysphoria to justify the rape (Whitehead 2009). Apparently it was 'more inspired by feelings of frustration and jealousy than sexual desire' (AB 2009, para 24). After the verdict, Jones was transferred to HMP Holloway.

Following this judgment, in 2011 the prison service reduced the segregation criterion from genital surgery to legal sex. 'A male to female transsexual person with a gender recognition certificate may be refused location in the female estate only on security grounds' (Ministry of Justice 2011, p. 5). This rule applied equally to women, as exceptionally dangerous women are held in men's prisons. Without legal certification, a transsexual who was 'sufficiently advanced in the gender reassignment process' could request to transfer to the estate of the other sex and was promised a case conference (p. 14). In practice, however, the request was rarely if ever granted. Presumably genital surgery without a gender recognition certificate would still enable transfer, but this point was moot as a certificate was much easier to obtain than surgery. It must have been this certificate that enabled Emma Bowman to be imprisoned in HMP New Hall, a women's prison, after being sentenced to eighteen months for drug offences. Bowman had previously been imprisoned for deliberately crashing into a woman's car and punching her (Brooke 2009). Before prison Bowman had taken cross-sex hormones and obtained breast implants, but had not had genital surgery. In New Hall he partnered with a female prisoner and temporarily stopped cross-sex hormones. According to one member of staff, 'he can still function as a man and that is quite scary in a prison full of female inmates' (Daily Mirror 2011).

Unintended interactions between the health system and the legal system had created a right for some males to be incarcerated with women. The changes were brought about piecemeal by judges and clinicians. Campaigners like Whittle and politicians like Carlile played a minor role, though they welcomed the erosion of sex segregation. These cases made for sensational reports in the tabloid press, usually emphasizing the cost of genital surgery, but there is no evidence that they attracted any public interest.

\section{Gender identity}

'Increasing positive, well-informed representations of transgender people in the media' was the aim of Trans Media Watch (n.d., p. 4), created in 2009. A key figure in the organization was Paris Lees, who came out as transgender after serving eight months in borstal for a violent robbery (Lees 2013b). Lees started writing for the Guardian in 2011. The newspaper also featured columns from a transgender prisoner across the Atlantic, Chelsea Manning, whose starring role in Wikileaks ensured a sympathetic audience (Lees 2013a; Manning 2014). The most famous transgender prisoner, however, was fictional. Orange is the New Black, a television series set in a women's prison, featured a character who had committed fraud to fund genital surgery, played by Laverne Cox. Time chose Cox to personify the 'transgender tipping point' in 2014. The series was a hit in Britain, and Cox gave a lengthy interview to the Guardian in 2015 (Nicholson 2015).

Just a few months later, Tara Hudson was convicted of assault for headbutting a barman, causing serious dental injuries. Given Hudson's record of eight previous convictions, including battery, Hudson was sentenced for twelve weeks. Reading about the case in the local newspaper, Cerian Jenkins, an undergraduate at the University of Bath, was outraged. She was already an activist, having founded the Bath Gender Equality Network 'for 
intersectional, sex-positive feminists'. ${ }^{6}$ She launched an online petition to demand Hudson's transfer to a women's prison (Jenkins 2015a, 2015b). The hashtag \#IseeTara proliferated on Twitter, with the very first tweet directed at Parliament's Women and Equalities Committee, which was holding an enquiry into transgender equality. The petition had extraordinary success, gaining 125,000 signatures within three days. Hudson's plight was publicized by newspapers from the Guardian to the Daily Telegraph (Gayle 2015; Sanghani 2015). Why did this particularly case catch the public imagination? Hudson looked glamorous with long blonde hair and 'really big boobs' (in the words of Hudson's mother). The petition stated that Hudson had 'undergone six years of gender reconstruction surgery', which falsely implied genital surgery. Hudson's mother spoke eloquently on her child's behalf. Conceivably Hudson also had a knack for publicity, as just months before a tabloid reported Hudson's success in entertaining men on Playboy Television Chat (Saunders 2015). Hudson who lived in Bath, was convicted and imprisoned in Bristol; the latter was home to a large progressive leftist community, including transgender activist Cheryl Morgan (2015). A final consideration in Hudson's favour was that Hudson had not committed violence against a woman, and was sexually attracted to men.

People who took up the cause were outraged because they viewed Hudson unambiguously as a woman. The petition stated that Hudson had 'lived as a woman all her adult life'. In a men's prison, therefore, Hudson would be subject to 'constant and terrifying sexual harassment' (Jenkins 2015b). Although Hudson had taken cross-sex hormones for several years, there is a hint of a more complicated identity: 'When I'm modelling for glamour shoots I feel like the sexiest girl alive, no-one has any idea that I'm actually a bloke' (Saunders 2015). Hudson advertised on adultwork.com as a 'shemale' with a '7inch surprise' (Rea 2015). From the point of view of the prison system, the fact that Hudson neither had obtained a gender recognition certificate nor had genital surgery meant that Hudson should be treated as a man. Hudson was confined in a private cell and initially not allowed to mingle with other prisoners. "There was a lot of banter-one guy I knew from back home asked to see my boobs. ... At the time I didn't see it as harassment or aggression-it was just "we love you", "we're your fan club", "try and come onto our wing" and so on' (Sanghani 2016).

Hudson's sentence was appealed. While the judges refused to grant the appeal due to Hudson's 'worrying criminal record', they did suggest removal to a women's prison (Gayle and Rawlinson 2015). There were demonstrations outside the court in Bristol and the Ministry of Justice in London. The latter was organized by C.N. Lester, a singer with a graduate degree from Goldsmiths who identified as genderqueer, and Ruth Pearce, a sociology student at the University of Warwick, writing a doctoral thesis on transgender health. Hudson's cause was taken up by the Member of Parliament for Bath, a Conservative, who fortuitously sat on the Women and Equalities Committee. The Ministry of Justice quickly transferred Hudson to a women's prison, HMP Eastwood Park. Hudson had spent just seven days in a men's prison. Arguably this move did not actually violate the 2011 regulations which, after all, enabled any transsexual to request a transfer to a prison of the opposite sex. There is no record of such a request being granted, however, and anyway a discretionary transfer fell far short of the demand now made. For Hudson's supporters, Hudson should have automatically been placed in a women's prison because Hudson identified as a woman. 'Girls show their emotions, they cry and they self-harm but males when they have got a problem they just let it out with violence', according to Hudson (Hopkins 2015). The irony went unremarked.

Within a few weeks, two transgender prisoners died in prison. Vicky Thompson, aged 21, was found hanged while on remand for theft. The offence had occurred while Thompson was serving a suspended sentence for assaulting and robbing a mother and daughter. Thompson

\footnotetext{
${ }^{6}$ She identified as queer a year later, but evidence of her identity at this time is lacking.
} 
did not have a gender recognition certificate, and had never taken cross-sex hormones. According to a prison official, Thompson 'did not want to go to a women's prison because other prisoners would be "bitchy" (Prisons and Probation Ombudsman 2015, p. 8). The tragic death - which an inquest later concluded was intended as self-harm rather than suicide (Pidd 2017) — was interpreted through the transgender lens. Other contributing factors were ignored: bipolar disorder, heroin use, and sexual and physical abuse. (Thompson had been taken into care as a baby and raped at the age of twelve.) Stonewall, the prestigious campaigning organization for lesbian and gay rights, had embraced the transgender cause in 2013. It used Thompson's death to reiterate its demand for gender recognition certificates to be given on demand. 'We now urgently need a change in the law to ensure trans people can live freely as themselves without fear of violence or intimidation' (Quinn 2015).

Edward Latham committed suicide while serving a life sentence for attempting to murder a woman and subsequently trying to kill two other inmates. He was held in HMP Woodhill's Close Supervision Centre, for the most dangerous prisoners. Latham announced that he was Muslim early in 2015 and made plans to change his name, but three months later he asked to be recorded as having no religion. In August Latham declared himself to be a woman, taking the name Joanne. The prison immediately supplied feminine clothing and cosmetics (Prisons and Probation Ombudsman 2016, pp. 6-7). Any transfer to a women's prison was out of the question; an equally dangerous female would also be held in the Close Supervision Centre of a men's prison, because women's prisons lack provision for extremely violent inmates. Nevertheless, Latham's death was used as further evidence of systematic injustice against transgender people (Allison and Pidd 2015). It is worth noting that male prisoners are more prone to suicide than female prisoners, though the disparity is not as great as among the general population (Ministry of Justice n.d.).

These two deaths compounded the protest over Hudson, followed by the opening salvo in a judicial review (Bhatt Murphy 2015). In December the government announced a fundamental 'Review into the care and management of transgender offenders' (Ministry of Justice 2015a). Possibly this could be attributed to the Home Secretary, Theresa May, who evinced more sympathy for the transgender movement than most Conservatives. ${ }^{7}$ Alternatively, it might have been spurred by proceedings for a judicial review. ${ }^{8}$ The review included two independent advisers. One was Peter Dawson, deputy director of the Prison Reform Trust. The other adviser was Jay Stewart, the chief executive and co-founder of Gendered Intelligence. Founded in 2008 with funding from the Equality and Human Rights Commission, Gendered Intelligence symbolized how the transgender movement was embedded within the political system. Like Whittle, Stewart initially came out as a lesbian and subsequently identified as a man. 'Queer theory was the roadmap to my own selfunderstanding', declared Stewart (2018, p. 278). Stewart had just earned a doctorate from Goldsmiths, with a thesis entitled 'Trans on Telly'. The thesis cites Butler 72 times, more than any other scholar (Stewart 2015).

Butler's worldview was reflected in the review, published in late 2016. It took 'as its starting presumption a wish to respect someone in the gender in which they identify.' 'Allowing transgender offenders to experience the system in the gender in which they identify will, in the great majority of cases, represent the most humane and safest way to act' (Ministry of Justice 2016a, p. 4). The review took evidence from transgender prisoners, but apparently met no women prisoners. Despite taking eleven months to produce, the report

\footnotetext{
${ }^{7}$ She had launched a plan for transgender equality (HM Government 2011). When she became Prime Minister, she announced legislation for self-declared gender identity.

${ }^{8}$ Hudson's 2015 legal action fizzled out, but was relaunched in 2018 (Townsend 2018). The Ministry of Justice (2020c) will reveal only that 'this claim has been concluded'.
} 
comprised only six pages of text. Its principles had to be translated into 58-pages of detailed regulations (Ministry of Justice 2016b). As had been the case since 2011, prisoners who possessed a gender recognition certificate would be allocated according to legal gender. (Now it also sufficed to have applied for a certificate.) Other transgender prisoners - defined as those who 'wish to live consistently in the gender with which they identify (opposite to the sex assigned [sic] at birth)'-would be asked whether they wanted to be housed in the male or female estate. This choice need not be consistent with their gender; a male who identified as a woman, for example, could also choose a men's prison. If a prisoner wanted to be housed in the estate of the opposite sex, a Transgender Case Board would quickly convene to consider the evidence (Ministry of Justice 2016b, p. 28). Genital surgery counted as strong evidence, but so did 'Advice from GP' (what sort of advice was not specified). In accordance with Butler's notion of gender performativity, strong evidence also included 'Presents in the gender identified with', and 'Change of name'. There was some acknowledgement, however, of other motivations for claiming a transgender identity. The list of counter evidence included 'may be linked to gaining access to future victims', 'seeking to undermine or test the policy', and 'Personality disorder diagnosis and/or narcissistic traits'. The review had warned that 'it will be necessary to factor-in the impact on and risks to those ... in the women's estate where many prisoners will have been the victims of domestic violence or sexual abuse' (Ministry of Justice 2016a, p. 5). Such risks were not mentioned in the regulations.

The previous criteria - initially genital surgery, then possession of a gender recognition certificate-were clear. The new criterion, however, was highly ambiguous. How these myriad factors could be evaluated by the Case Board in practice is left to the imagination. Moreover, officials would know that refusal to grant the wishes of a transgender prisoner could lead not just to negative media coverage but also to internal scrutiny. The National Offender Management Service created a Transgender Advisory Board-whose members included Stewart-'to inform policy and establish best practice' (Gendered Intelligence 2017).

Before the 2015 review was completed, there was already evidence to challenge the assumption that males who proclaimed a transgender identity automatically deserved to be treated as women. The British Psychological Society (2015) wrote about 'a number of cases where men convicted of sex crimes have falsely claimed to be transgender females'. Several motivations were specified: 'demonstrating reduced risk and so gaining parole; ... explaining their sex offending aside from sexual gratification (e.g. wanting to 'examine' young females); ... separating their sex offending self (male) from their future self (female); ... seeking better access to females and young children through presenting in an apparently female way'. These risks were echoed by the president of the British Association of Gender Specialists (2015). The president was none other than Barrett, who in 2009 had been unconcerned about women having to share facilities with a violent rapist. Now he described 'the ever-increasing tide of referrals of patients in prison serving long or indeterminate sentences for serious sexual offences.' Some prisoners were motivated to 'pretend transsexual status' for the same reasons laid out by the British Psychological Society. For one particular individual, there was 'a plethora of prison intelligence information suggesting that the driving force was a desire to make subsequent sexual offending very much easier'. The Women and Equalities Committee ignored these written submissions, just as it ignored submissions from dissident feminists (e.g. Campaign to End Rape 2015). The Committee's report concluded only that 'There is a clear risk of harm (including violence, sexual assault, self-harming and suicide) where trans prisoners are not located in a prison or other setting appropriate to their acquired / affirmed gender' (Women and Equalities Committee 2016, p. 86). How this would affect females was of no concern to the Women's and Equalities Committee. 


\section{Consequences}

The new regulations formally came in to effect at the beginning of 2017. They were already applied, however, in the case of Jenny Swift, remanded to HMP Doncaster for attempted murder in November 2016. Transgender case conferences led to a recommendation that Swift be transferred to the female estate. After the victim died and the charge was upgraded to murder, Swift committed suicide. Media coverage focused on the prison's failure to provide Swift with cross-sex hormones, which had been purchased online without any prescription (Fae 2017). This failing was criticized by the Prisons and Probation Ombudsman, even though the NHS Gender Identity Clinic had actually decided that 'Swift was not in a sufficiently stable position to go any further with the gender reassignment process' (Prisons and Probation Ombudsman 2017, p. 12). The cessation of hormones was blamed for Swift's mood swings. This is hard to square with the fact that Swift, while on hormones, had stabbed a man multiple times with a kitchen knife and then beat him with a broken shovel (Sandhu 2017).

The number of transgender prisoners increased following the new regulations. The first statistics were collected in the beginning of April 2016. There were 70 transgender prisoners, defined as 'currently living in, or are presenting in, a gender different to their sex assigned at birth' and as having had a case conference under the 2011 regulations (Ministry of Justice 2016, p. 2). This number excluded prisoners with a gender recognition certificate, like Karen Jones. The new regulations came into force in January 2017. Three months later the number of transgender prisoners had almost doubled to 125 (Ministry of Justice 2017, p. 13). The growth might have reflected the new dispensation which incentivized prisoners to declare a gender identity. The number of males in the women's estate was not recorded. A dissident feminist organization, Fair Play for Women, estimated this figure by combing through the reports of individual prisons, predominantly from 2017 and 2016. They found reference to 13 males in women's prisons; the total was likely to be higher (Fair Play 2017). One of them was Jessica Winfield, moved to a women's prison, HMP Bronzefield, in March 2017 (EleftheriouSmith 2017). As Martin Ponting, he had been sentenced to life in 1995 for raping two girls. Around the same time, five males were transferred to another women's prison, HMP New Hall (Hamilton 2017). The first official figures distinguishing between the men's and women's estates were provided for the beginning of April 2018. The total number of transgender prisoners had increased modestly from 125 to 139 . There were 42 transgender prisoners in the women's estate: 22 of them identified as female, 17 as male, and 3 gave no response (Ministry of Justice 2018a, p. 17). It seems implausible that there were as many as 17 females identifying as transmen in women's prisons; one suspects that these figures reflect confusion over classification among inmates or officials. ${ }^{9}$ Prisoners with a gender recognition certificate were not counted as transgender, moreover, and so the figure of 22 will underestimate the total number of males in women's prisons.

The plight of transgender prisoners continued to attract attention even after the 2016 regulations had partly institutionalized the demands of transgender activists. A report on 'the health and social care needs' of transgender prisoners was produced by Community Innovations Enterprise (2017), a Limited Liability Partnership controlled by Lord Patel of Bradford. The report acknowledged assistance from Gendered Intelligence and Stephen Whittle, and featured an epigraph by Judith Butler. Lord Patel launched the report by inviting Karen Jones to Parliament to speak on 'raising awareness of transgender issues in the criminal justice system' (Hall and Fielding 2018). The speech did not mention that Jones had killed a man and attempted to rape a woman (Andersson 2019).

9 The website transcrime.co.uk, which collates news reports, lists only two transmen incarcerated at this time, Jay Ferguson and Adam Bonser. 
Incarcerating males with women would inevitably lead to sexual assault. This consequence was ignored or denied by transgender activists and by politicians and officials. Conceivably some assumed that all transgender males, like Tara Hudson, were sexually attracted to men - and so would pose no sexual threat to women. In fact, many are sexually attracted to women. Moreover, changes to prison policy now provided incentives for sex offenders to identity as transgender-just as Barrett and the British Psychological Society had warned. Inmates wrote cynically about 'trans-jesters' or 'trans-imposters' who could now dodge the Sex Offenders Treatment Programme: 'Happy days for any sex offender who is willing to pull on a pair of tights and change their name to Crystal or Mimsi for the duration' (T.C. 2016; also see Anonymous 2016). From its own research, Fair Play for Women estimated that $41 \%$ of transgender males were sex offenders. This proved to be an underestimate. Of the 125 transgender prisoners counted by the prison service in 2017, 60 had been convicted of sexual offenses, including 27 convicted of rape (BBC News 2018). In the overall prison population, by comparison, $19 \%$ of males had been convicted of sexual crimes and only $4 \%$ of females (Ministry of Justice $2018 b$ ).

There was an allegation that Winfield was placed in segregation in August 2017 for sexually propositioning inmates in HMP Bronzefield, though this was denied by other sources (Eleftheriou-Smith 2017). ${ }^{10}$ The first proven sexual attack by a male transgender prisoner in England happened in the following month. Karen White was charged with multiple counts of raping a woman along with burglary and stabbing a man. White was remanded to a women's prison, HMP New Hall, despite being legally male and having previously served eighteen months in prison for sexually assaulting a child; the prison houses a mother-and-baby unit. It is not clear why White's history of offending did not dictate incarceration in a male prison, but officials were arguably following the new guiding principle-'a wish to respect someone in the gender in which they identify.' Unsurprisingly, White sexually assaulted four inmates in New Hall, touching and hugging them and displaying an erect penis (Evans, McCann, and Rudgard 2018). ${ }^{11}$ After two months White was transferred to the male estate. White was subsequently sentenced to life imprisonment.

To argue that Karen White represents the apotheosis of queer theory is provocative. Yet criminologist Sarah Lamble-Reader in Criminology and Queer Theory at Birkbeck-boldly defended White's womanhood in a seminar on 'Trans prisoners, sex segregation and the queer politics of safety' (Lamble 2019). Why exactly White should be classified as a woman remained unclear despite much discussion of 'the surface and depth of gender/sex embodiment'. In my reconstruction, the intuition requires two moments. The first moment is the performative move, which is straight out of Butler, and indeed echoed in the 2016 regulations. 'When the constructed status of gender is theorized as radically independent of sex, gender itself becomes a free-floating artifice, with the consequence that man and masculine might just as easily signify a female body as a male one, and woman and feminine a male body as easily as a female one' (Butler 1990, p. 6). Tara Hudson successfully performed a version of femininity, in presentation (long hair and makeup) and in physique (cross-sex hormones and breast implants); this performance meant that over a hundred thousand people signed the petition to have Hudson moved to a women's prison. White's performance, by contrast, was perfunctory. According to Jenny-Anne Bishop, who led the local transgender support group, White 'insisted people referred to her in her acquired gender without trying terribly hard to present as a woman' (Parveen 2018). 'Other than wear a wig and put on women's clothing, she has made no more effort' reported a transgender neighbour.

\footnotetext{
${ }^{10}$ A transgender inmate did commit sexual assault at HMP Bronzefield, but the details are unknown (Brown 2020).

${ }^{11}$ White admitted two counts of indecent assault and two other counts were laid on file.
} 
The neighbour described White as 'more transvestite than transsexual with no real desire to be a woman', observing that White had missed three appointments at a gender identity clinic (Bannerman and Lister 2018). Lamble's presentation included a photograph of an unshaven White looking uncannily like an overweight middle-aged man. (No insult is intended because I am likewise an overweight middle-aged man.) Preceded by a trigger warning, the image was used to illustrate the cruelty of Fair Play for Women, who used it in their campaign against proposals to amend the Gender Recognition Act.

If White did not succeed at performing femininity, on what grounds was White a woman? In practice, the first moment is followed by a second, in which performativity is augmentedor rather superseded - by anti-essentialism. It is wrong, after all, to insist that women must perform femininity. Thus Lamble argued that White's failure to attend the gender clinic did not detract from White's womanhood, just as a woman who misses an appointment for a cervical smear is not considered less of a woman. In a similar fashion, Lamble asserted that excluding White from women's prisons would also entail excluding a butch lesbian. Queer theory equates them because both 'identify' as a woman. In sum, then, anti-essentialism undercuts performativity to leave only declaration: a woman is any person who claims to be a woman. Words are all that matter.

When treating the question of 'safety/danger', Lamble downplayed the offences committed by White in prison, emphasizing that 'non trans women' have done worse. It is true that the offences in prison were not terribly serious. However, there was a clear risk of escalation if White continued in a women's prison (as Lamble apparently would have wished). A therapist with access to White's record discerned 'a history of seeking access to mixed and women's institutions to find and abuse vulnerable people', including a psychiatric hospital where he allegedly raped a young woman (Gilligan 2018). This previous conduct was not mentioned by Lamble. Nor was White's exploitation of the power of the state, even though Lamble (2013) has criticized the LGBT movement's deployment of state power to punish hate crime. Bishop noted that White 'would report people for a hate crime if they stumbled over which name to use' (Parveen 2018). A neighbour likewise recalled White 'always calling the police accusing us of hate crimes' (Bannerman and Lister 2018). In sum, Lamble's seminar demonstrated how a 'queer transformative justice perspective' can transmute an extremely violent and sexually predatory male into a vulnerable victim deserving protection from transphobic feminists and the carceral state. The transmutation was no idiosyncrasy of Lamble's, for it is deeply rooted in the genealogy of queer theory (Jones 2018). Foucault (1976, p. 31) notably characterized the sexual assault (or possibly rape) of a little girl as 'inconsequential bucolic pleasures', and condemned the girl's parents and the mayor for their 'collective intolerance' in reporting it to the gendarmes.

\section{Conclusion}

After the case of White became public in 2018, the process of replacing sex by gender identity was halted. HMP Downview opened a new wing for 15 transgender prisoners, separated by a fence from the buildings for female inmates - though they still have contact when using the gym and attending courses (Gilligan 2019; Hellen 2019). Regulations were revised to emphasize 'a balanced approach which considers the safety and needs of those who are transgender, whilst ensuring that decisions do not negatively impact on the well-being and safety of others, particularly in custodial settings such as in women's prisons' (Ministry of Justice 2019a, p. 2). Ultimately, however, what happens in the prison system depends on the framework established by the Gender Recognition Act. After all, prisoners 'must be treated in accordance with their legally recognized gender in every respect' (p. 6). The previous Conservative Prime Minister, Theresa May, promised to amend the legislation to enable anyone to change their legal sex by declaration. Unexpected opposition from an odd coalition 
of dissident feminists and classical liberals has made any change unlikely under the current Conservative government. All the opposition parties, however, have promised to erase biological sex in accordance with queer theory.

In retrospect, what is striking is how policy has been animated solely by concern for male prisoners who identified as transgender. This is hardly unexpected from campaigners who identified as transgender, like Stewart or Whittle, though one might have expected some sympathy for women given their own biographies. What is really surprising is that their bias was shared by the key decision-makers who were not themselves transgender: whether a parliamentarian like Carlile, a clinician like Barrett, a judge like Elvin, a feminist like Jenkins, or a scholar like Lamble. No thoughts were spared for the women who they were forcing to be confined with males who had usually proven to be violent or sexually predatory or both. Women were treated as the audience needed to validate the performance of transgender identity. For the queer theorist, of course, female inmates lack the glamour of transgression. Why, though, did the judicial machinery of human rights make no attempt to balance the rights of females against the rights of transgender males? Some feminists will attribute the prioritizing of men's feelings over women's safety to patriarchy. This interpretation is undermined by the fact that so many of the protagonists are female. Many of them, moreover, view the struggle to place transgender males into women's prisons as the epitome of feminism, and their views are shared even by radical feminist Catherine MacKinnon (Williams 2015). When surveyed, women are more likely than men to accept transgender males who have not had genital surgery in women's prisons (Populus 2018); I estimate that women comprised a slight majority of the signatories to Hudson's petition (Jenkins 2015a). ${ }^{12}$ All this looks more like matriarchy than patriarchy. I suggest that transgender activism dovetailed with a progressive bias towards people who are positioned as victims of formal institutions of power-especially the state. This bias is common to the liberal discourse of human rights as well as the radical discourse of queer theory. In this perspective, it is progressive to champion the transgender prisoner contesting the power of the state and transgressing the dominant categories of society. Less obvious is the kind of informal power that can be exercised among individuals, such as that exerted by one inmate over another. The bias is compounded by the denial of behavioural differences between the sexes, which is shared by most varieties of feminism as well as queer theory (Biggs 2019).

A deflationary argument should be addressed. Why dwell on the threat posed by transgender males in women's prisons? White is an exceptional case, after all. Since 2010, out of 124 sexual assaults reported in the women's estate, only 7 were committed by transgender prisoners (Brown 2020). (The latter figure excludes any assaults perpetrated by prisoners who had acquired a gender recognition certificate.) A queer theorist might argue that this a small price to pay for the pleasure of disrupting binary categorization. Indeed, does not focusing on these handful of cases - rather than on the vast majority of assaults perpetrated by female prisoners - betray transphobia? This deflationary argument is fallacious because the transition from sex to gender in the prison system has not yet been implemented. The prison system proved conservative in practice, as campaigners lamented. The vast majority of males who identify as women are still held in men's prisons - nine out of ten according to the latest statistics (Ministry of Justice 2019b, p. 15). If campaigners for gender identity achieve their goal, then the number of males in women's prisons will multiply several times over. ${ }^{13}$ Given

\footnotetext{
${ }^{12}$ I scraped the first names of the most recent 950 signatories (Jenkins 2015a) and submitted them to genderize.io; the estimated female proportion is $58 \%$.

${ }^{13}$ Not all would choose to transfer, of course. Sarah Jane Baker, serving a life sentence for kidnapping and torturing one man and attempting to murder another, rejected the prospect of transferring because 'I like men! I'd never get a shag!' (Abraham 2019).
} 
the obvious incentive for heterosexual men to transfer, and the huge sex imbalance in the incarcerated population, males would soon outnumber females in women's prisons. The consequences for female inmates hardly needs to be spelled out.

Queer theory ultimately aims to decentre compulsory heterosexuality and to subvert identity. Its partial implementation in the prison system, however, did not achieve those aims. Incarcerating males in women's prisons turned out-unsurprisingly- to facilitate heterosexuality. The identity of 'woman' was successfully subverted, to be sure. The prison system no longer records the biological sex of inmates: forbidden from doing so for those with a gender recognition certificate; apparently choosing not to do so for others who declare a transgender identity. Paradoxically, though, subverting the traditional identity of woman, defined as adult human female, means creating novel identities-'woman' and 'transgender'- deriving from verbal declaration. These identities are now rigidly enforced by the formal machinery of law, and in elite social circles by the informal compulsion of norms. If the women sexually assaulted by White had needed to testify in court, the judge would have forced them to refer to their assailant with female pronouns (Ward 2018). This paper had to be written with special care to avoid transgressing the identities proclaimed by violent criminals. Thanks in part to queer theory, gender identity has become sacrosanct. 


\section{REFERENCES}

AB. R (on the application of AB) v Secretary of State for Justice and Another. 2009. EWHC 2220 (Admin).

Abraham, Amelia. 2019. What It's Like to Be Trans in the UK Prison System. Dazed, 6 November. http://www.dazeddigital.com/life-culture/article/46703/1/what-its-like-to-betransgender-in-the-uk-prison-system

Allison, Eric and Helen Pidd. 2015. 'Second Transgender Prisoner Found Dead in Male Jail.' Guardian, 1 December.

Andersson, Jasmine. 2018. 'These Powerful Stories from Two Trans Ex-Offenders Remind Us Why We Need to Support Trans Rights Today.' Pink News, 24 January. http://www.pinknews.co.uk/2018/01/24/these-powerful-stories-from-two-trans-exoffenders-remind-us-why-we-need-to-support-trans-rights-today/

Anonymous (HMP Littlehey). 2016. 'Trans-imposters.' Inside Time, 30 September.

British Association of Gender Identity Specialists. 2015. Written evidence submitted to the Women and Equalities Committee's Transgender Equality Inquiry. 20 August.

Bannerman, Lucy and Mark Lister. 2018. 'Rapist, Karen White, in Women's Jail "Was Trans Faker".' Times, 10 September.

BBC News. 2015. 'Calls for Transgender Woman to Be Moved from Male Prison.' BBC News, 27 October. http://www.bbc.co.uk/news/uk-england-somerset-34650486

BBC News. 2018. 'How Many Transgender Inmates Are There?' BBC News, 13 August. http://www.bbc.co.uk/news/uk-42221629

Bhatt Murphy. 2015. 'Tara Hudson Welcomes Transgender Policy Review.' http://bhattmurphy.co.uk/in-the-news/news-archive-4/archived-prisoners-rightsstories/tara-hudson-welcomes-transgender-policy-review

Biggs, Michael. 2009. 'Self-Fulfilling Prophecies.' Peter Bearman and Peter Hedström (eds), The Oxford Handbook of Analytical Sociology, Oxford: Oxford University Press, pp. 294314.

Biggs, Michael. 2019. 'How Feminism Paved the Way for Transgenderism.' Quillette, 1 August. transgenderism/

British Psychological Society. 2015. Written evidence submitted to the Women and Equalities Committee's Transgender Equality Inquiry. 20 August.

Brooke, Chris. 2009. 'Sex-Change Lorry Driver Jailed for Punching Neighbour Claims She Was Harassed.' Daily Mail, 19 February.

Brown, David. 2020. Seven Sex Attacks in Women's Jails by Transgender Convicts. Times, 11 May.

Burrell, Ian. 1999. 'Murderer to Get Sex Swap on the NHS.' Independent, 12 March.

Butler, Judith. 1990. Gender Trouble: Feminism and the Subversion of Identity. New York: Routledge.

Campaign to End Rape. 2015. Written evidence submitted to the Women and Equalities Committee's Transgender Equality Inquiry. 21 August.

Daily Mail. 1982. "Madam Stern" of Vice Racket Is Convicted by Jury As a Man.' 29 September.

de Lauretis, Teresa. 1991. 'Queer Theory: Lesbian and Gay Sexualities.' differences: A Journal of Feminist Cultural Studies, vol. 3, no. 2, pp. iii-xviii.

Dhejne, Cecilia, Paul Lichtenstein, Marcus Boman, Anna L.V. Johansson, Niklas Långström, and Mikael Landén. 2011. 'Long-Term Follow-Up of Transsexual Persons Undergoing Sex Reassignment Surgery: Cohort Study in Sweden.' PLoS One, vol. 6, no. 2, e16885. 
Dresch, Matthew. 2019. 'Worcester Transgender Woman, Previously Convicted of Rape, Breaches Order.' Worcester News, 25 January. http://www.worcesternews.co.uk/news/17384498.worcester-transgender-womanpreviously-convicted-of-rape-breaches-order/

Eleftheriou-Smith, Loulla-Mae. 2017. 'Transgender Rapist's Segregation in Women's Prison "Not Due to Sexual Advances on Inmates".' Independent, 6 September.

Emerton, Robyn. 2018. 'Transgender Prisoners: Law, Prison Administration, and the Emerging Tension between Human Rights and Risk.' PhD thesis, Law, Keele University.

Evans, Martin, Kate McCann, and Olivia Rudgard. 2018. 'Transgender Person Accused of Rape Is Remanded into Female Prison and Sexually Assaults Inmates Within Days.' Daily Telegraph, 6 September.

Fae, Jane. 2017. 'Jenny Swift Was a Trans Woman: She Should Not Have Died in a Male Prison. Guardian, 9 January.

Fair Play for Women. 2017. 'Investigation into the Number of Trans-Identifying Males in Prison in England and Wales and Their Offender Profiles.' http://fairplayforwomen.com/transgender-prisoners/

Fisher, Lucy and Fariha Karim. 2020. 'Change Law on Women's Spaces, says Rebecca Long Bailey.' Times, 17 February.

Ford, Richard. 2006. 'Inmate Goes from Man to Woman and Back on NHS.' Times, 12 January.

Foucault, Michel. 1976. The History of Sexuality, vol. 1: An Introduction. Trans. Robert Hurley. New York: Vintage Books.

Francis, Bill. 2013. 'Sex-Swap Lag's Wedding Chop.' Daily Star, 20 January.

Garside, Richard. 2018. 'Transgender Prisoners.' 11 September. http://www.crimeandjustice.org.uk/resources/transgender-prisoners

Gayle, Damien. 'Transgender Prisoner at HMP Bristol "Being Sexually Harassed".' Guardian, 29 October.

Gayle, Damien and Kevin Rawlinson. 2015. 'Transgender Woman Moved from Men's to Women's Prison.' Guardian, 30 October.

Gendered Intelligence. 2017. Annual Report, 2016-17.

Gilligan, Andrew. 2018. 'Why Was Convicted Paedophile Allowed to Move to a Female Jail?' Sunday Times, 9 September.

Gilligan, Andrew. 2019. “Europe's First Jail in a Jail” for Trans Women' Sunday Times, 2 March.

Goodchild, Sophie. 2000. 'Prisons Inspector Calls for Sex Change Ops.' Independent on Sunday, 13 February.

Hamilton, Michael. 2017. 'Lags Trans-Fury: Staff and Inmates at New Hall Prison Are Fearful after Five Transgender Cons Were Placed in the All-Women's Jail.' Sun, 30 April.

Hall, Emily, and James Fielding. 2018. 'Transgender Activist Jailed for Killing Her Boyfriend and Trying to Rape Shop Assistant Five Days after Being Released from Prison Is Invited to Speak at House of Lords.' Daily Mail, 27 February.

Hellen, Nicholas. 2019. 'Female Prisoner Takes Government to Court after Alleged Assault by Transgender Inmate.' Sunday Times, 3 November.

Home Office. 2019. Offences Currently Recorded as Homicide, Where Victim is Aged 16 or Older, by Sex of Victim and Where the Principal Suspect Has Been Convicted of Homicide, Committed Suicide or Died, 2006/07 to 2016/17. Freedom of Information request, 51751.

Hopkins, Steven. 2015. Transgender Prisoners: Cases of Tara Hudson, Vicky Thomson and Joanne Latham Reveal Deepening Crisis. Huffpost, 14 December. 
http://www.huffingtonpost.co.uk/2015/12/14/transgender-women-prisons-tara-hudsondeaths_n_8760608.html

HM Government. 2011. Advancing Transgender Equality: A Plan for Action.

Interdepartmental Working Group. 2000. Report of the Interdepartmental Working Group on Transsexual People. London: Home Office.

Jagose, Annamarie. 1997. Queer Theory: An Introduction. New York University Press.

J[enkins], Ceri[an]. 2015a. 'Stop Transgender Woman Tara Hudson From Being Sent to an All-Male Prison in Bristol.' http://www.change.org/p/bath-magistrates-prison-govenor-ofhm-prison-bristol-british-judicial-system-stop-transgender-woman-tara-hudson-frombeing-sent-to-an-all-male-prison-in-bristol

Jenkins, Cerian. 2015b. 'Why I Started the Petition to Save a Trans Woman from an All-Male Prison.' Independent, 29 October.

Jones, Jane Clare. 2018. 'Queer Theory, Foucauldian Feminism and the Erasure of Rape.' $\mathrm{http}$ ://janeclarejones.com/2018/08/30/queer-theory-foucauldian-feminism-and-theerasure-of-rape/

Lamble, Sarah. 2013. 'Queer Necropolitics and the Expanding Carceral State: Interrogating Sexual Investments in Punishment.' Law and Critique, vol. 24, pp. 229-253.

Lamble, Sarah. 2019. 'The Surface and Depth of Gender: Trans prisoners, Sex Segregation and the Queer Politics of Safety.' Seminar at the Department of Criminology, University of Oxford, 14 February.

Law Society of Ireland. 2019. 'Male-bodied Transgender Inmate Housed with Women.' Gazette, 18 October. http://www.lawsociety.ie/gazette/top-stories/male-bodiedtransgender-inmate-housed-with-women-prisoners/

Lees, Paris. 2013a. "I hope Chelsea Manning Gets the Help She Needs": Paris Lees, Transgender Former Prisoner, on Life Inside.' Guardian, 23 August.

Lees, Paris. 2013b. 'From Bullied Child to Transgender Woman: My Coming of Age.' Guardian, 15 December.

MacKenzie, Donald A. 2006. An Engine, Not a Camera: How Financial Models Shape Markets, Cambridge, Mass: MIT Press.

Manning, Chelsea E. 2014. 'I Am a Transgender Woman and the Government Is Denying My Civil Rights.' Guardian, 8 December.

Meierhans, Jennifer. 2015. 'Is a Gender Recognition Certificate Crucial or Cruel?' BBC News Online, 20 November. http://www.bbc.co.uk/news/uk-england-34832811

Mirror. 2011. 'Sex Swap Lorry Driver's Relationship with Killer at Women's Jail.' 24 July.

Ministry of Justice. n.d. 'Deaths in prison Custody, 1978 to 2015.' http://assets.publishing.service.gov.uk/government/uploads/system/uploads/attachment_da ta/file/519428/safety-in-custody-deaths-to-2015.xls

Ministry of Justice. 2011. The Care and Management of Transsexual Prisoners. PSI 07/2011.

Ministry of Justice. 2015a. Review into the Care and Management of Transgender Offenders: Written Statement made by the Parliamentary Under-Secretary of State for Justice, Minister for Women, Equalities and Family Justice (Caroline Dinenage). 8 December. http://www.gov.uk/government/speeches/review-into-the-care-and-management-oftransgender-offenders

Ministry of Justice. 2015b. Official Statistics: Prisoner Transgender Statistics, March/April 2016, England and Wales.

Ministry of Justice. 2016. The Care and Management of Transgender Offenders. AI 13/2016; PSI 17/2016; PI 16/2016.

Ministry of Justice. 2018a. Her Majesty's Prison and Probation Service: Offender Equalities Annual Report, 2017/18. 
Ministry of Justice. 2018b. Prison Population, 31 March 2018. http://assets.publishing.service.gov.uk/government/uploads/system/uploads/attachment_da ta/file/702300/population-31-march-2018.ods

Ministry of Justice. 2019a. The Care and Management of Individuals who are Transgender.

Ministry of Justice. 2019b. Her Majesty's Prison and Probation Service: Offender Equalities Annual Report, 2018/19.

Ministry of Justice. 2020a. Prison Population, 31 December 2019. http://assets.publishing.service.gov.uk/government/uploads/system/uploads/attachment_da ta/file/861890/Population_31Dec2019.xlsx

Ministry of Justice. 2020b. Freedom of Information Act request, FOI 200100504. 22 January.

Ministry of Justice. 2020c. Freedom of Information Act request, FOI 200226034. 24 March.

Morgan, Cheryl. 2015. 'Trans and the Law: Theory and Practice.' Cheryl's Mewsings, 26 October. http://www.cheryl-morgan.com/?p=21668

More, Kate. 1996. 'Proposals for the HM Prison Service: Review of Guidelines Relating to Transsexual Prisoners.' Radical Deviance, vol. 2, pp. 78-82.

More, Kate and Butler, Judith 1999. 'Never Mind the Bollocks, 2: Judith Butler on Transsexuality.' Kate More and Stephen Whittle (eds), Reclaiming Genders: Transsexual Grammars at the Fin de Siècle, London: Cassell, pp. 285-302.

Murray, Kath and Lucy Hunter Blackburn. 2019. 'Losing Sight of Women's Rights: The Unregulated Introduction of Gender Self-Identification as a Case Study of Policy Capture in Scotland.' Scottish Affairs, vol. 28, pp. 262-89.

Nivette, Amy E. 2011. 'Violence in Non-State Societies: A Review.' British Journal of Criminology, vol. 51, pp. 578-98.

Rebecca, Nicholson. 2015. 'Laverne Cox: "Now I Have the Money to Feminise my Face I Don't Want to: I'm Happy That This Is the Face God Gave Me".' Guardian, 14 June.

Parveen, Nazia. 2018. 'Karen White: How "Manipulative" Transgender Inmate Attacked Again.' Guardian, 11 October.

Pidd, Helen. 2017. 'Transgender Woman at Male Prison Did Not Mean to Kill Herself, Jury Finds.' Guardian, 19 May.

Playdon, Zoë-Jane. 2004. 'Intersecting Oppressions: Ending Discrimination against Lesbians, Gay Men and Trans People in the UK.' Belinda Brooks-Gordon, Loraine Gelsthorpe, Martin Johnson, and Andrew Bainham (eds), Sexuality Repositioned: Diversity and the Law, London: Hart Publishing, pp. 131-52.

Populus. 2018. Gender Recognition Act survey. 19-21 October.

Prisons and Probation Ombudsman. 2015. Independent Investigation into the Death of Ms Vicky Thompson, a Prisoner at HMP Leeds on 13 November 2015. London.

Prisons and Probation Ombudsman. 2016. Independent Investigation into the Death of Ms Joanne Latham, a Prisoner at HMP Woodhill on 27 November 2015. London.

Prisons and Probation Ombudsman. 2017. Independent Investigation into the Death of Ms Jenny Swift, a Prisoner at HMP Doncaster on 30 December 2016. London.

Quinn, Ben. 2015. 'Partner of Transgender Woman Found Dead in Prison Calls for Law Change.' Guardian, 20 November.

Rea, Samantha. 2015. 'Mainstream Media A Mouthpiece for Tara Hudson's Mother.' Medium, 22 November. http://medium.com/@Samantha_J_Rea/mainstream-media-amouthpiece-for-tara-hudson-s-mother-10b6c2c74147

Sandhu, Nathan. 2017. 'Dad-of-Two Brutally Knifed to Death by Transgender Woman in Boozy Drug-Fuelled Rage.' Daily Record, 19 October.

Sanghani, Radhika. 2015. 'Tara Hudson: British Prisons Have a Serious Problem with Transgender People.' Telegraph, 28 October. 
Sanghani, Radhika. 2016. 'Tara Hudson: "The Harrowing Reality of Being a Trans Woman in an All-Male Prison".' Telegraph, 15 January.

Saunders, Josh. 2015. 'Playboy TV Chat Glamour Model with 34E Breasts Who Has Seduced 1,000 Men Reveals 'I'm Actually a Bloke".' Mirror, 2 September.

Stewart, Jay. 2015. 'Trans on Telly: Popular Documentary and the Production of Transgender Knowledge.' PhD thesis, Goldsmiths College, University of London.

Stewart, Jay. 2018. 'Gendered Intelligence.' Christine Burns (ed.), Trans Britain: Our Journey from the Shadows, Cornerstone, pp. 277-91.

Swerling, Gabriella. 2020. 'Hammer-Wielding Trans Woman Escapes Prison after Judge Hears There Was No Way to Confirm Her Gender.' Telegraph, 27 February.

T.C. (HMP Wandsworth). 2016. 'Trans-jesters.' Inside Time, 1 December.

Townsend, Mark. 2018. 'Transgender Woman Sues over Ordeal in Male Prison.' Observer, 21 January.

Trans Media Watch. n.d. 'Memorandum of Understanding.' http://www.transmediawatch.org/Documents/Memorandum\%20of\%20Understanding.pdf

Trans Crime. 2019. 'Transgender Individuals Who Have Killed/Attempted to Kill Others in the UK.' http://transcrimeuk.com/2017/12/16/transgender-individuals-who-have-killedattempted-to-kill-others-in-the-uk/

Turner, Camilla. 2019. 'Open University Forced to Cancel Conference Following Threats from the Transgender Lobby.' Telegraph, 20 March.

Ward, Victoria. 2018. 'Radical Feminist Warned to Refer to Transgender Defendant as a “She” During Assault Case.' Telegraph, 12 April.

Whitehead, Tom. 2009. 'Transsexual Prisoner Wins Right to Be in Female Prison.' Daily Telegraph, 4 September.

Whittle, Stephen. 2002. Respect and Equality: Transsexual and Transgender Rights. London: Cavendish Publishing.

Whittle Stephen and Lewis Turner. 2007. "Sex Changes"? Paradigm Shifts in "Sex" and “Gender" Following the Gender Recognition Act?' Sociological Research Online, vol. 12, no. 1.

Whittle, Stephen, Lewis Turner and Maryam Al-Alami. 2007. Engendered Penalties: Transgender and Transsexual People's Experiences of Inequality and Discrimination. Equalities Review.

Williams, David. 2006. 'Victims Condemn Prisoner's £50,000 Sex Swop [sic]'. Daily Mail, 13 January.

Williams, Kim, Vea Papadopoulou, and Natalie Booth. 2012. Prisoners' Childhood and Family Backgrounds: Results from the Surveying Prisoner Crime Reduction (SPCR) Longitudinal Cohort Study of Prisoners. Ministry of Justice Research Series 4/12.

Williams, Cristan. 2015. 'Sex, Gender, and Sexuality: The TransAdvocate Interviews Catharine A. MacKinnon.' TransAdvocate, 7 April. http://www.transadvocate.com/sexgender-and-sexuality-the-transadvocate-interviews-catharine-a-mackinnon_n_15037.htm

Women and Equalities Committee, House of Commons. 2016. Transgender Equality: First Report of Session 2015-16. London: The Stationery Office. 